は厶か提おシれはイいュ

し不のら起けョへ直シま二現

加可急問しるンと接 $コ さ ケ$ 代

し能激题てコは移的ンらイの

なでなにいミ新行な・とシ社

があ変するュたしゅメて会

らる华ると二索て

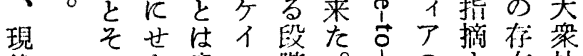

代のよ晸 シ階。高の专在社

の重、知 $\exists$ そ蹬るが会

社要そのン到れの達ま桠で

会落と事が達とのとでめあ

と機飞実多しと阅相的てる

ら能おでくた係圆な璉と

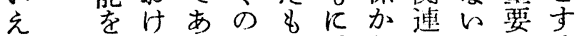

ど顧るるる困の流となる

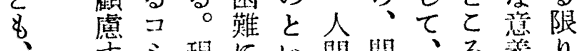

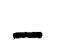

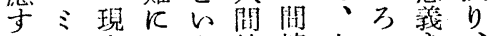

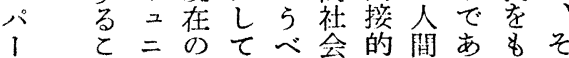

ソと社々会な相るすと

ナ寺不会か、お立。的

ルくシをつそけンのマのお

- ᄂ 3 ᄂ゙のるパ間スでけ

コてンの複よコ1の・ある

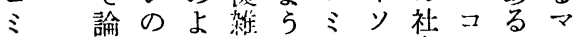

ュずメらなな゙て

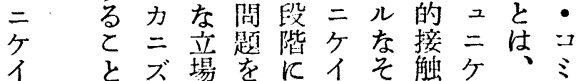

て的とミニ関とな1れンい段シ の進をュケサ連い意ソるののとコ

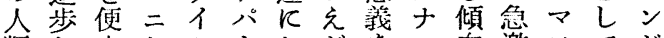
類乙宜々シ1市どをル向激スてが 反た的イ

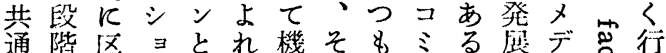

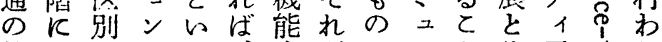

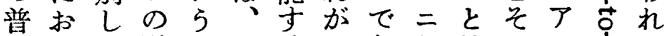
遍い得過べるパあケはのの市て 的てる程きミ\&1るイ事重出艺い 現のとをつュのソ。シ実要現のな 象み守基二でナマョで性にのい で現る易䂫ケあルスンあのよ接わ あれ。な的イる・・はる故る触け るる台技シてロメが住がで

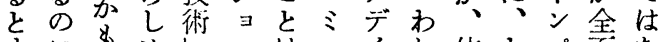

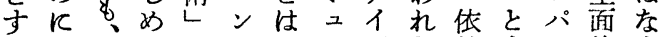

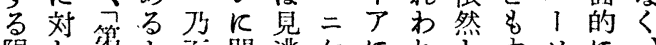

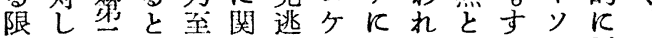
りて次と忙しイよのしれナ否コ

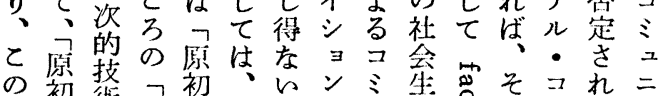

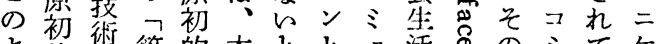
上的呰第的本とと工活

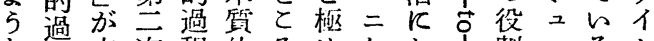
な程文次程的乃めケお市剽二る

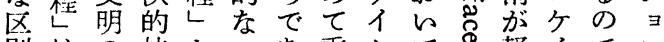
別はの技とコあ重シてて軽イでン

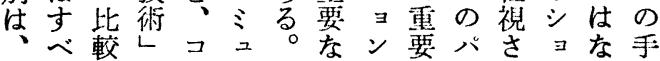

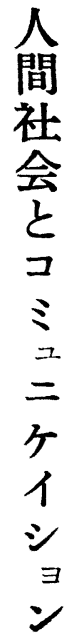

\title{
生
}

田

正

- 輝 


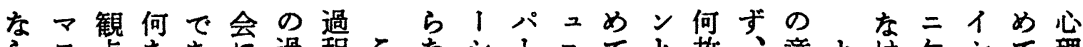
ら点なあ反過程となシ! こてと故意とけケシて理

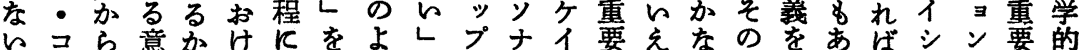

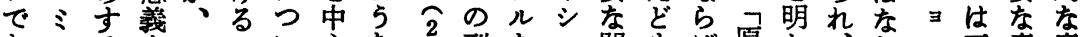

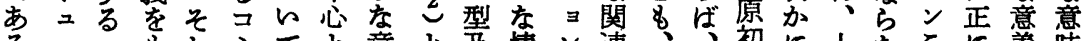
$\zeta=コ$ を 5 ケミつて之若し味述び報のを決高的卞閏々そとがに

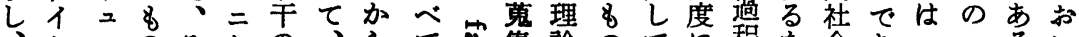

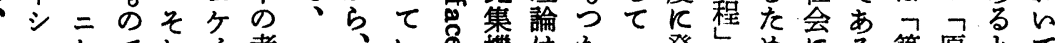
クョケでれイ考一、に市機はか子発をめ反ろ第原とて

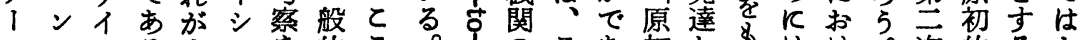
レのシる人 3 を的と。市のラあ初し含け。次的ると

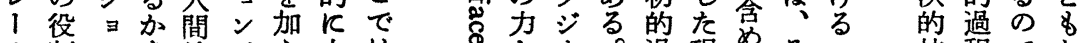
の割ンを社がえ人はをを程でか らをの明会、ん間主 み方考汃社

じり察にお体专会し

くょてしr、る \&くそたで゙お お サ 指理は如の.のけパ 摘解現け何よでるな しす現けなる゙るする゙ 如前のし機持。二わ のと、等代て考のミ

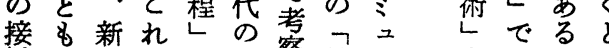
触飞聞飞と社察第二さをあ

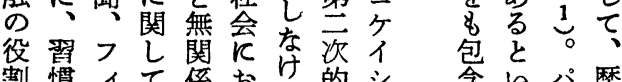

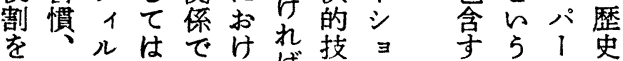

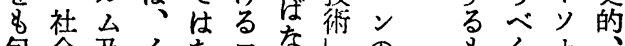

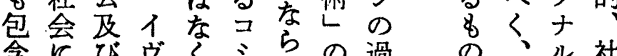

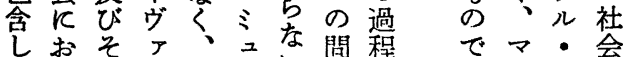

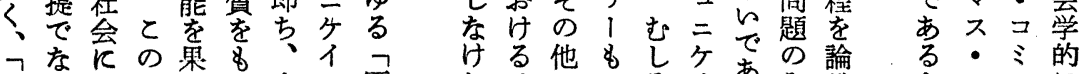

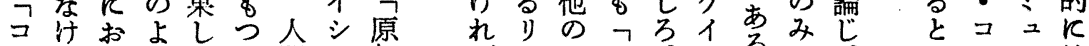

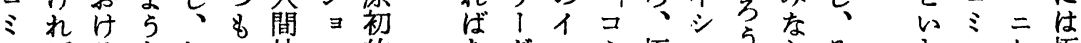

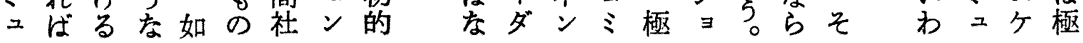

表しよとのさ来記ろ 情 ヴらす個せ号とコ 態ジ広い体る制令わ゙ 度 $\exists$ 得他留と蕒れ=

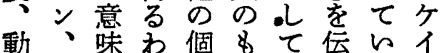
作映でけ体の受充るシ 画把でのでけるがョ さの握あ行あ手過、ン ら如专る動るに程こが にをる。をとなをと何

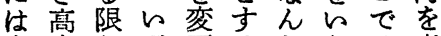
音度りず更るららは意 声飞、れ娄なかの、味 、発そにるらので送夺 言達のせ刺げ反ありる 語し手上戟木応る手兮 文段なを木を。がと

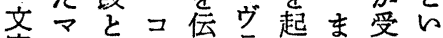
字不しミ達引さ店 5

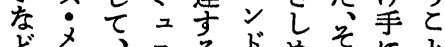

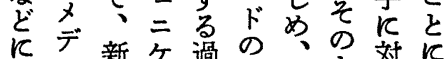

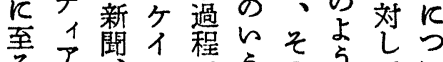
るア閔シで5 の まはラョあ如行な記なて ですジンるく動号記な

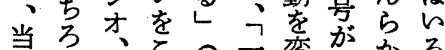

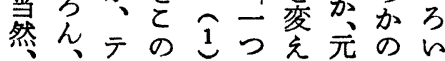

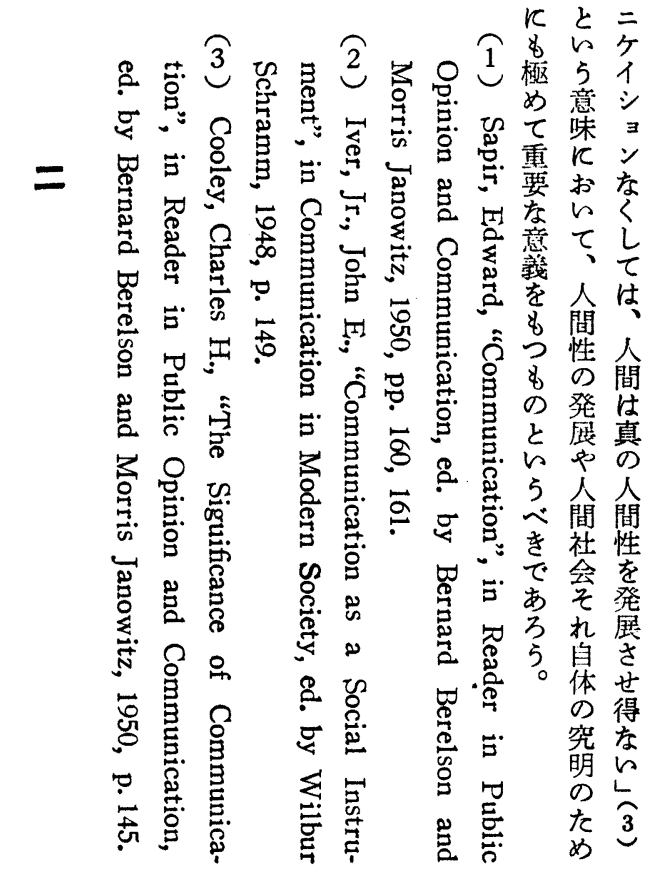




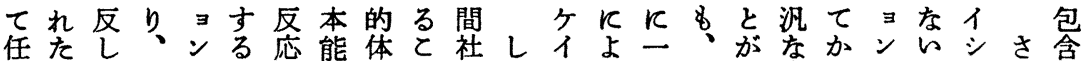
意行て殆も遭は的系と会かシる定そ出音なはとョてさ 的為、ん、伝、メKKの机のれ来声り存とン、れ シ様人ど同的他力あ注そなン百結がる、高在はがそな ン式間本様傾の二つ目れがのの合なと表度す明、のけ ボを社能に向集ズてしと方存接かんと情にるか。これ

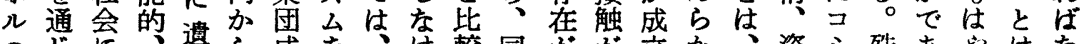

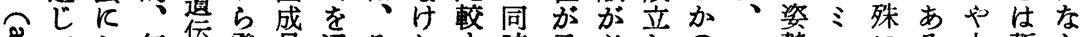

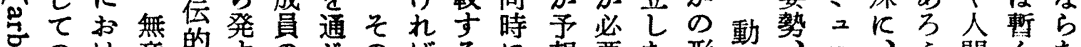

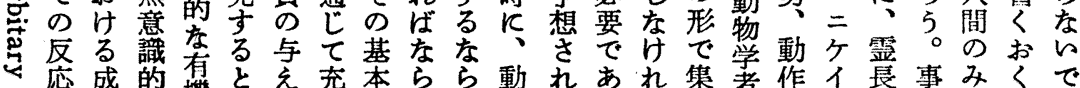
応成的機と充本らら動れあれ集者作イ長事みくで

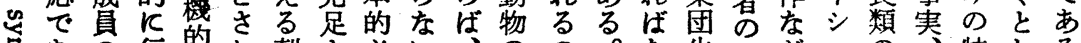
るあの行的れ刺さ必的のの特しろ

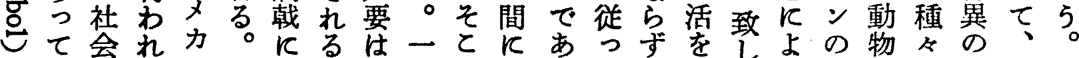

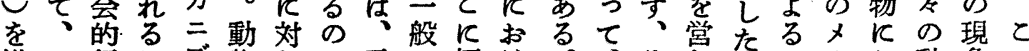

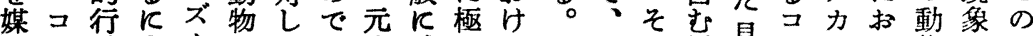

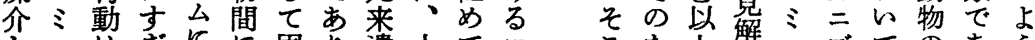

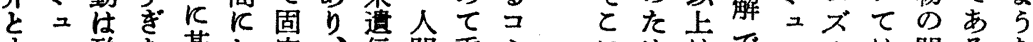

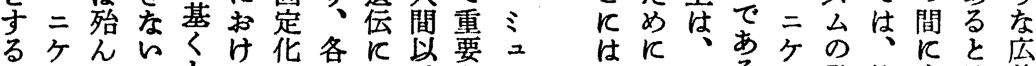

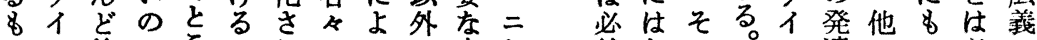
のシ後でてされのうの本ケ然なの㗢洼のコ必で でョ吴あろミた成てあ質イ 的ん成動当が動ミ导の

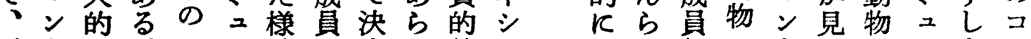
デ\& $\lessdot$ そ二式の定ゆ差 イ主学てれケで社さる異ンミの互い行れ此ケいュ ヴと習れでイ反会れ社のを様のえ5 較イい二 イしさKあシ応的る会あ人二式間どと広しシ得ケ

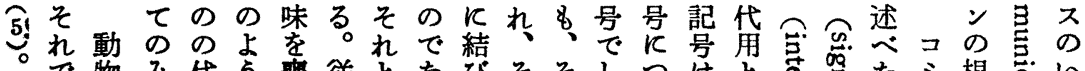

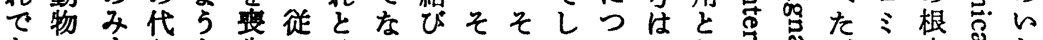

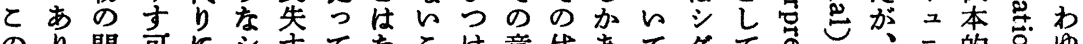

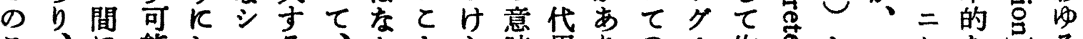

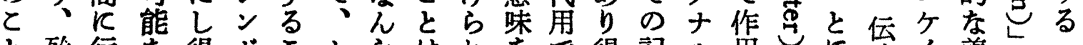
と殆行な得ボこシらはれをで得記儿用しに達イ差、フ

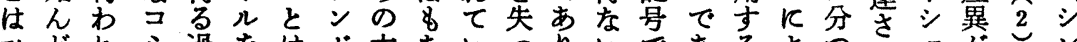

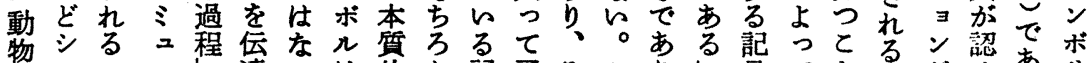

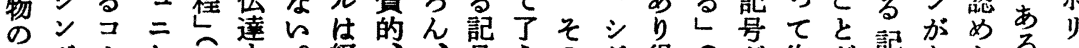

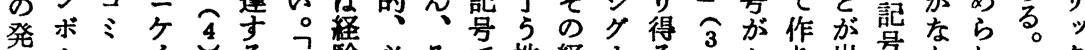

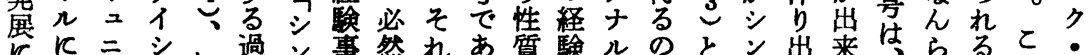

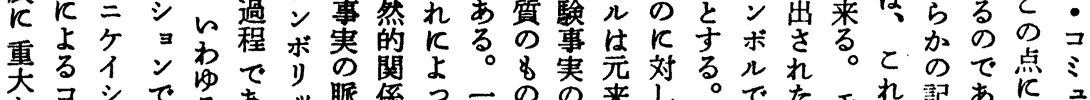

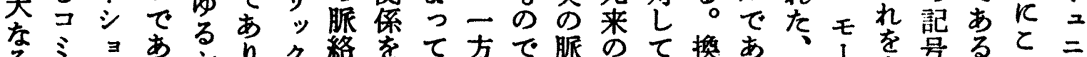

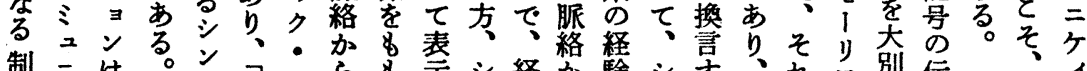

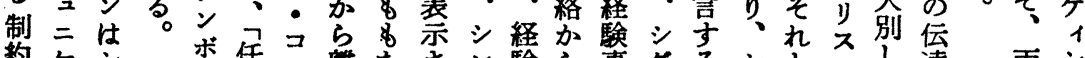

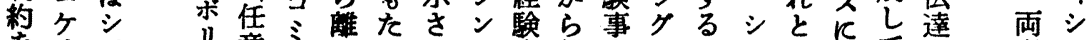

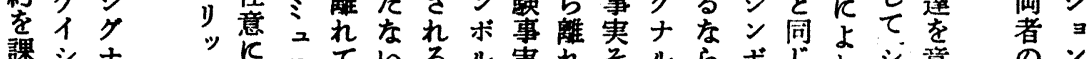

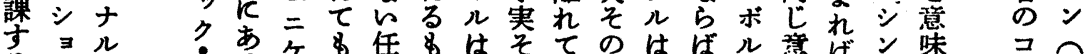

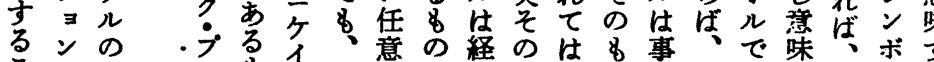

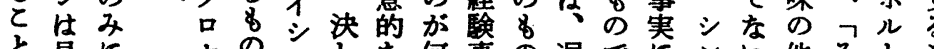

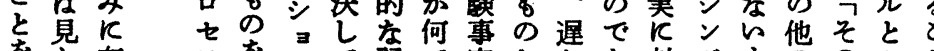

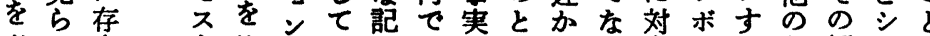

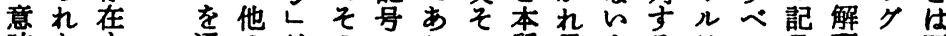
味な道のはのでれの留早まるはて号积ナ既

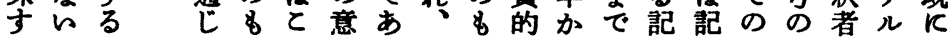




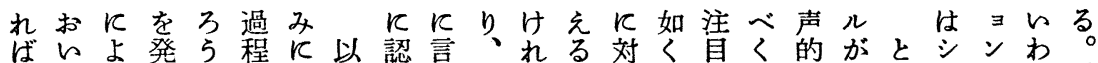

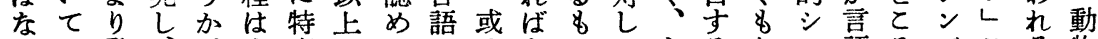
らで発、次人有にらのるなのて主るなン語ろボてる物 なあ揮音人間のおれみ意らと刺と必らボででルそ以の らろさ味類社\&んなな味なし戟し要がルあ、的は所集 で5れあ会のてけらにいてをてが、とる人動人村 あか発る特及で、れ亦お。言聴あ他して間物間とが

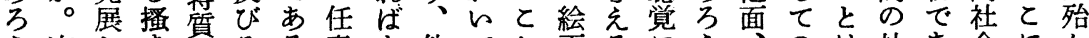
5 次しをとそる意な他てれ画るに5、のは社あ会に儿

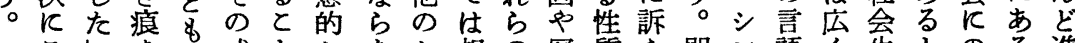
こしを呼成とシなシ相の写質え即ン語く生とのる進

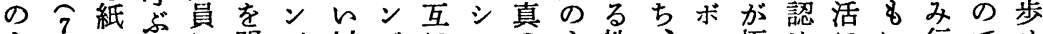

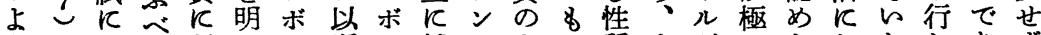
5 としを対かル所儿補ボよの質人がめらおわわすすす

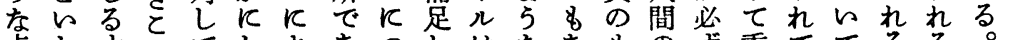

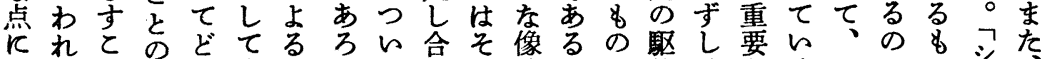

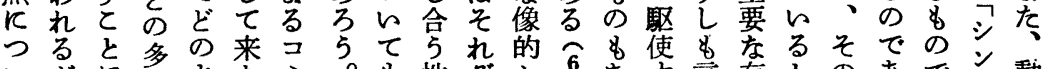

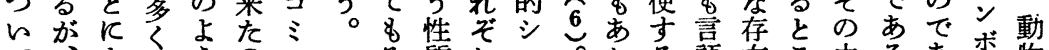

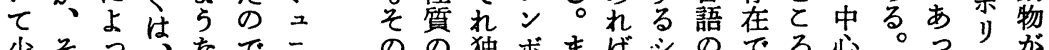

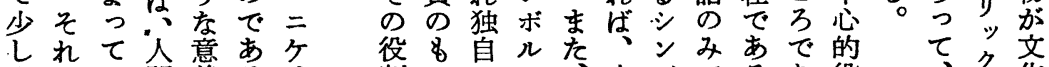
くはの間義るイ 考如協がをがシ 察何同意多、 をなと味つとン 加るらあも字が 意 5 る の よ な味能物でら間 けに力音あなの

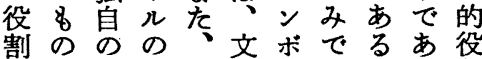
ので特存同字ルはとる割 重す質在様のになと。を 要らを游は如は確果

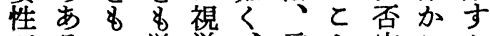

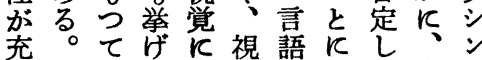
分単おな訴覚の得音ボ
?文化

ᄃ

の ミ \&

意

味 二 得 でケな 人 間 シと

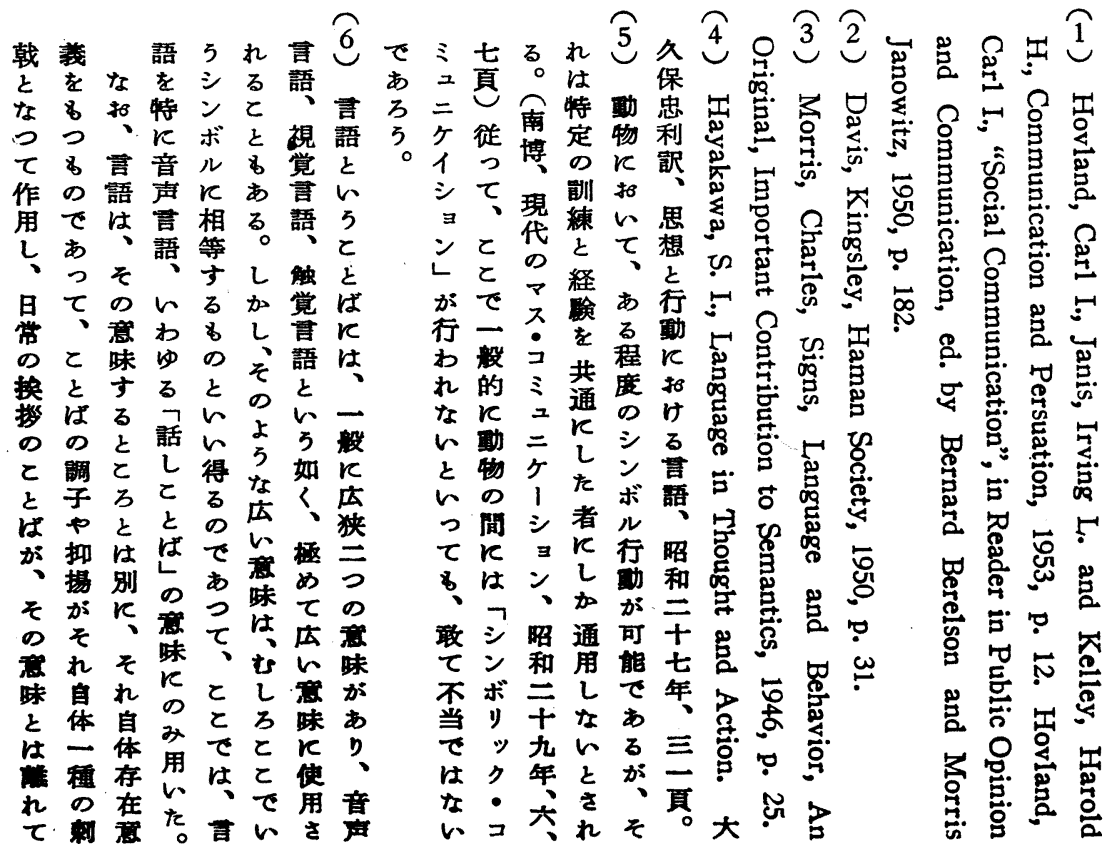


雑応飞市すずる動るれ的

な学と重る、と物のるな動

社翼れ要とらとにで環集物

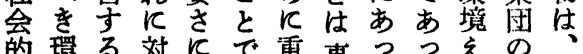

的環る対供で重事つつ方の

文境能しおあ要事てての形た

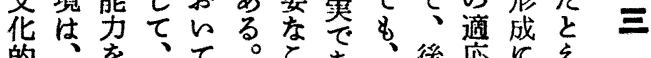

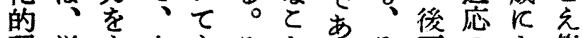

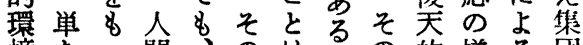

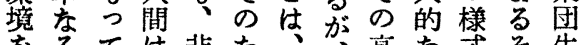

をるては非た、市高式そ生

含鼻々此常めそそ級学柇れ活

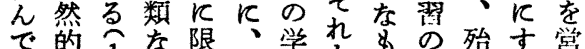

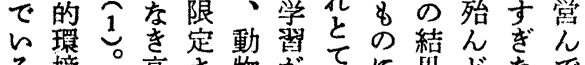

る境。高さ物がてに果ぼなで

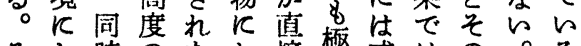

そと時のたお接極或はの。る

のどに可\&け的める生従に

よま塑のる経て程的得つし

5 ら性と学験制度。的飞元

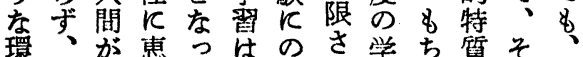

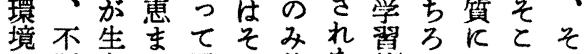
え断存れ了の依た能んる反れ

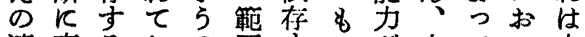
適変るおの囲守の茫人てい本 応動たりでにるに涩間決て能 は等め、あお方婝見的 るに無るんのさら外さ出有 生複適限。てでされのれさ機

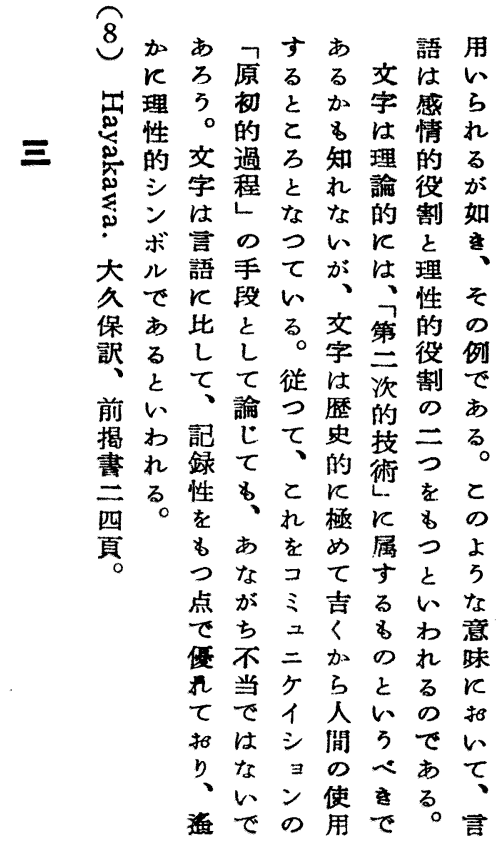

8 かあフすああ語用 誌理亏初点加字感 性 ○的 2 \& 山情れ 的交過万知理的当 紊字程をれ れ 論役が

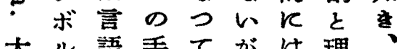
久で段い、性そ 保あ比と可交第的の 訳 乙兄。字三役例 前い、論つ歴的のあ 揭为記して史技三る

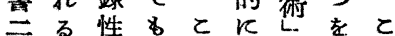
四。老、机極飞务の

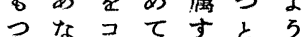
点がミ吉るいな でちュくるわ意

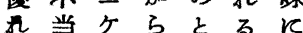
てでイ人いの扣 扔はシ閏了でい りな 海での角でる。言

く的 K化しるシ\&ゆ達定机とでにと特イイつなる得

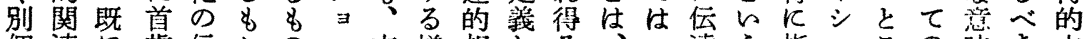

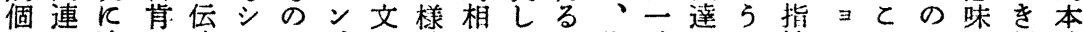
飞を述し達ンと、花式互てと集致さと摘ンろみに衍能 そもへ得Kボん殊をの作いと団しれとしがで生お為的

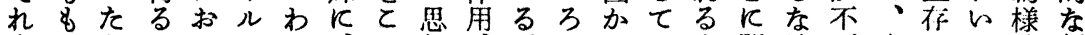

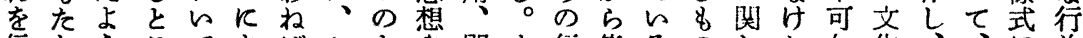

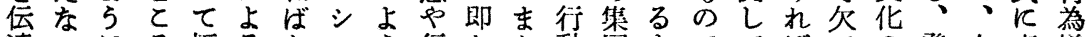

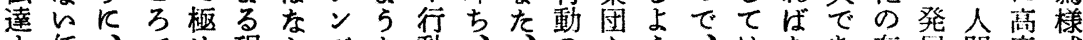

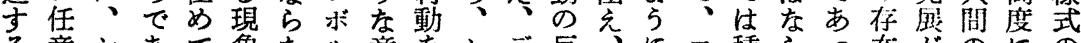
る意シあて象なル意をシデ反、にコ種らっ在がのにの

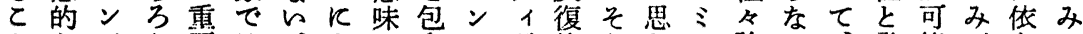
となボ5要は。上飞含ボヴ的

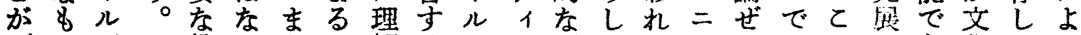
可のが役にたる解るに型てるケらあれのあ化なる 能で経割ともミすしょもで世。イれろらたるをけて であ験をししニるふるるつあ代たシでののめとをれは

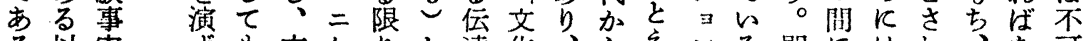

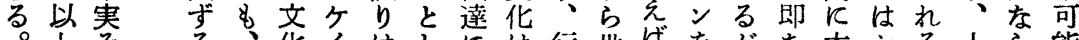

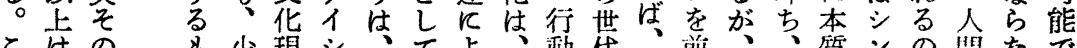

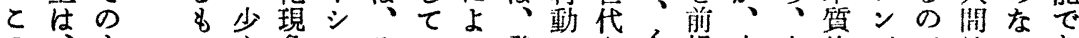

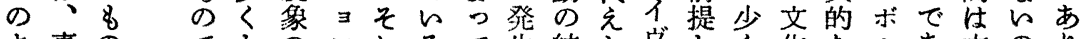

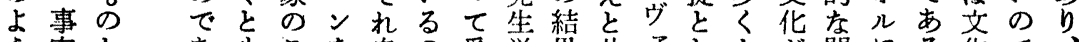

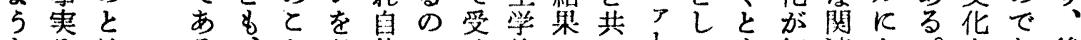

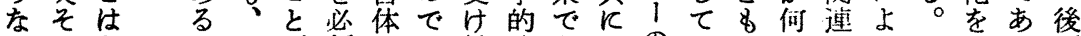

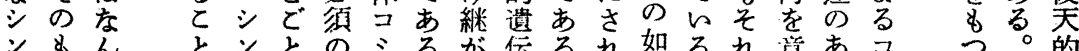

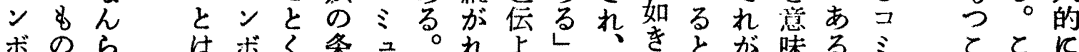

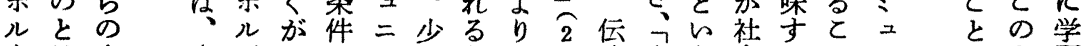

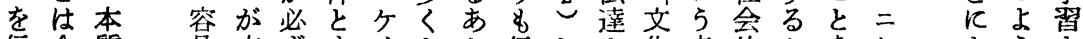
伝全質易文ずすイとら伝とさ化点的かをケなる 
的化予人可二歩たとスあ極 ウ相のでニ人し環間のえ 遺は测間能ケが経とピるめまエ互機あケヶて境的でる 産、寸はでイ期験が!がてだル関能るイは自の継あこ

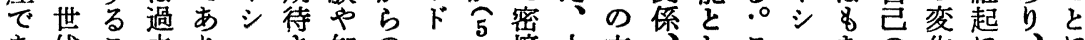

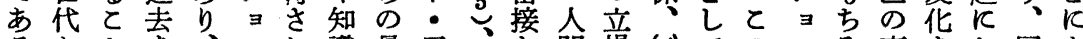

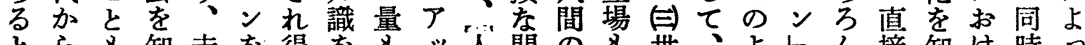

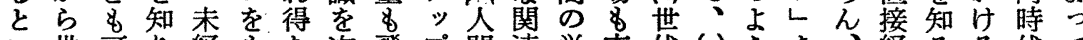
的哥り経名な次飛プ間連学充代 え代能、験ついの躍すは翼分か環な通前験たコの

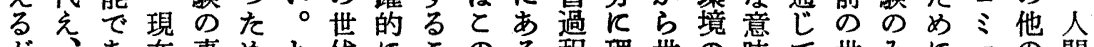
が氵 あ在事めと代にとのる程理世の味て世みにュの間 集りを赛にとに堌とメとが解代監飞知代に、二個は

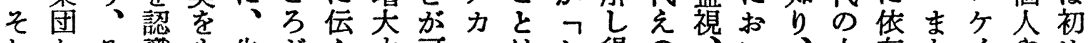

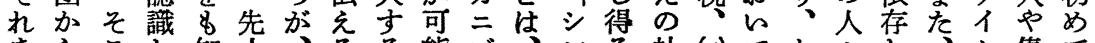

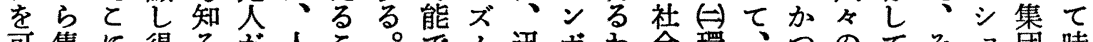
可集飞得るが人と。で㕕迅ボわ会環りつのてそョ団時 能団進ると残間と如あを反り的境社、経的ンの間 に充歩のとしはが何る通ホッで遗に会そ験るにがみと 寸とがみがたシ不にのじヴクあ産反にれを方対可な空

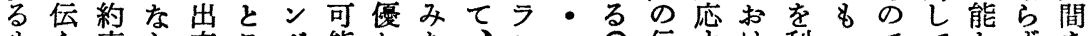

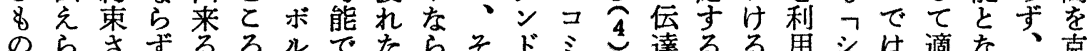

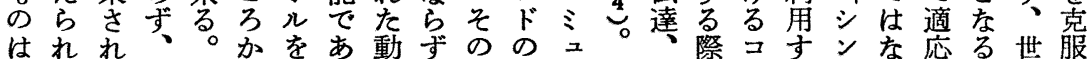

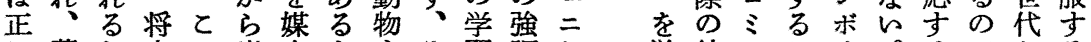

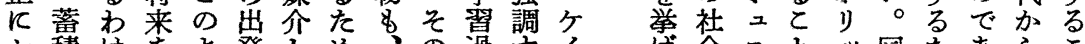
シ積けをよ発とめ、の過子イけげ会ニとッ同たあらと

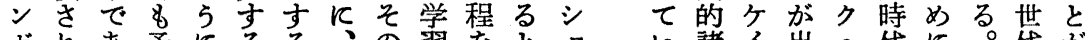

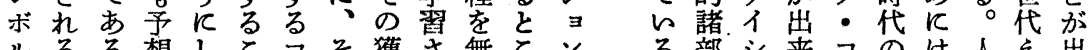

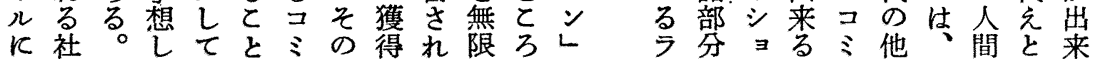

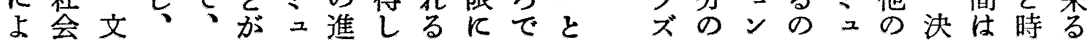

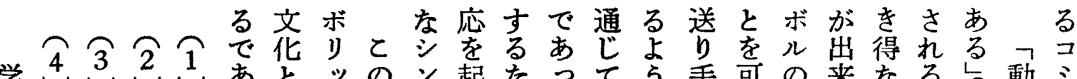
社 あとッのン起方ってら手可の来なる動ミ ろのクよボさめて、に自能故ないの 6 物

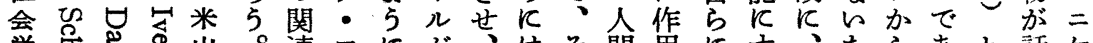

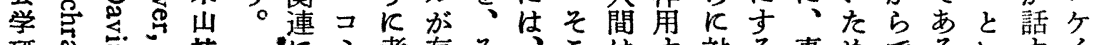

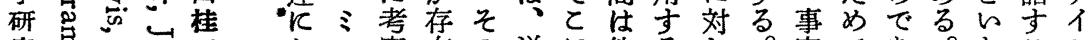

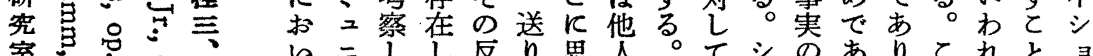
室马?

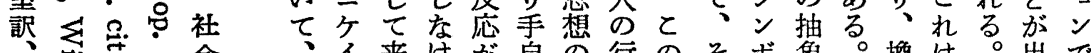
它官会、来けが自の行のそボ象。換は。出で マ害学如シるれ自身発為よれル化と言動即来あ

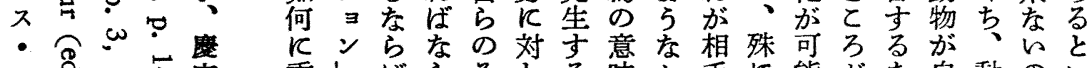

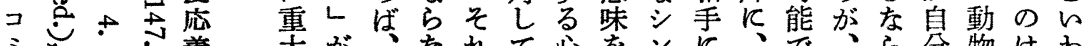
義大が、なれて心をンに、分物はわ 二点憼 な不人いか相理自ボ与音あ人ばでは、な 役可間のら手学已ル充声り間、自考話け 割欠のであ反的のKる的、自分方导れ をの社あと起な経よとシ抽場ら自なへば 果存会るのさ基験る同ン象合を身いをな

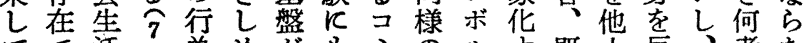

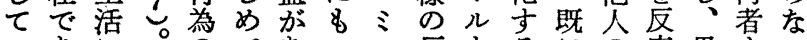

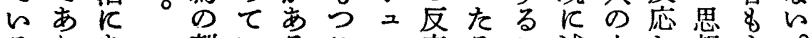

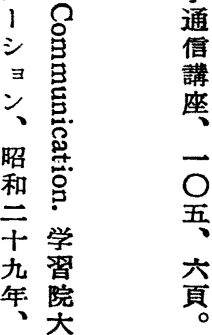
るりあ刺りると二応ると述立し想も か、つ戟る。とケを言とへ場得をた

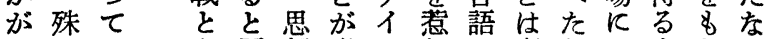
理には年想出シ起は考如お立たい

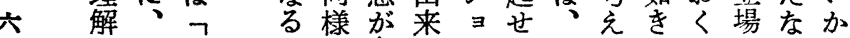

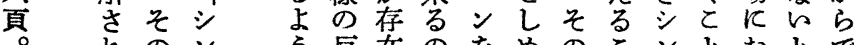


つ文るつ開气とでたらん

と依、文つ社! しあとからと し存所の市会导てつとのか机 てし詮でる在のてろコのが

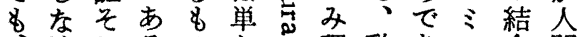
けれるのな理動あこ合間 一れは。でる岕解物る二がで 人壮一人結邑さ集。ケ存あ の香間る合导杂団じ在れ 個らのがと以しるがかシしし、 人個如同上との管しョ動 がら人何時のしにななきけ物 社。のKK\&対るががれで 会まよ文、の把し生ら行ばあ 的市华々で握て物市なれ、 遗人な礼古さ社間る势集 の間得蓄文、䅡間会社必、団 悉がる積炛成ば社的会要そ生 く如と、の員な会体はのの活 を何と登一の宛系文あたを

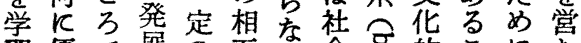

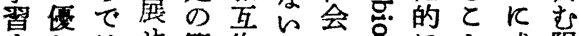
守れはせ範作の・文飞と成限 るたなし域用で、文务規は筫り

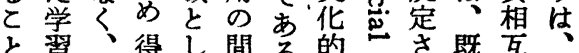

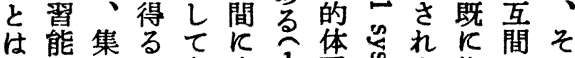

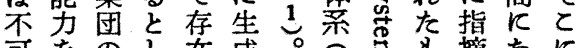
可をのし在成。今寻字摘な 能的力守し人?巳のしんな

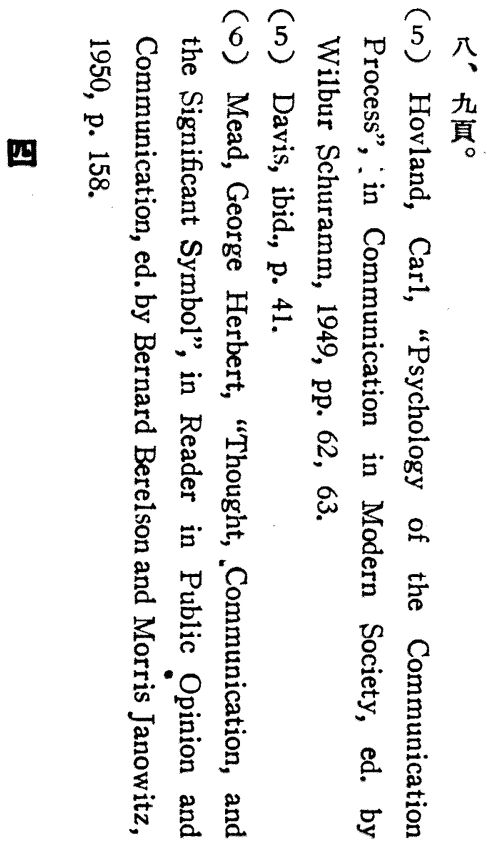

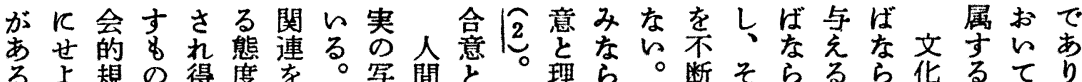

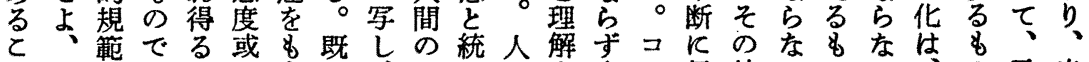

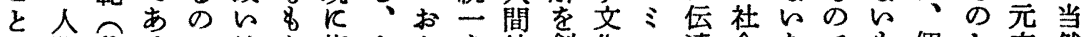

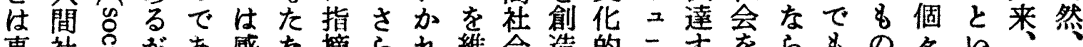
事社号汃あ感な摘られ維会造的二すをら\&の々い

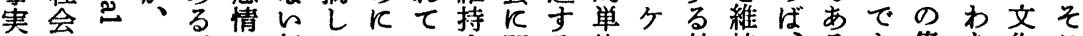

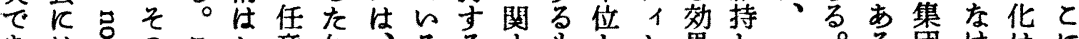

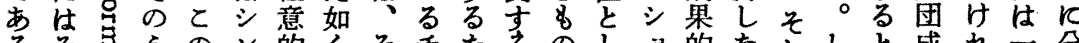

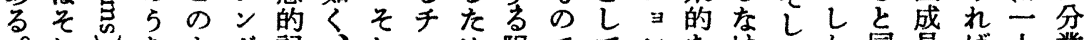
○れちよボ記、れこめ限でてンなけてか同員ば人業

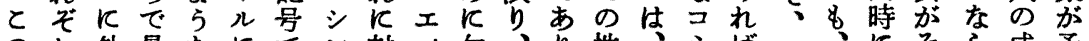
のれ外最なにでン対1久、り性、ミ佂社飞そら成予

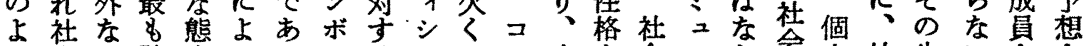
与会ら強度るるルるョさミ少を会二ら会人社生的さ な的な力やコなが態ンがく附及艿な威が会存。りれ

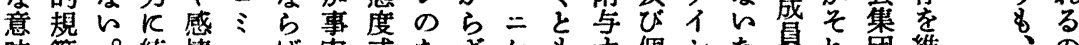
味範。統情ュば実或なざ方個シな間れ団維り の

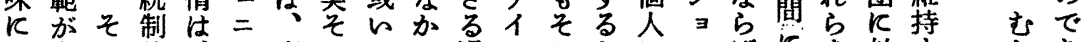

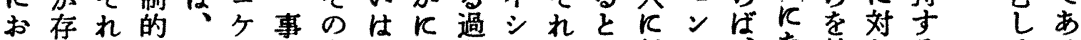

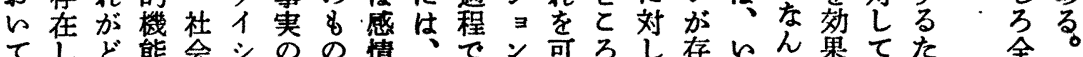

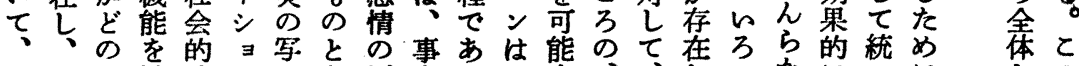

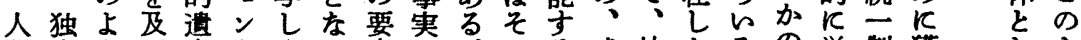

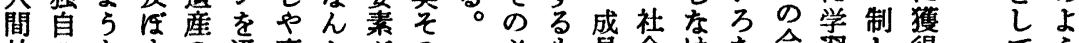

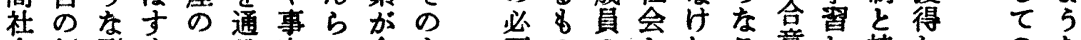

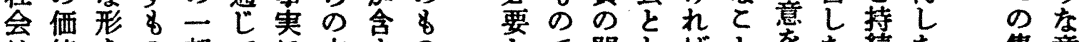

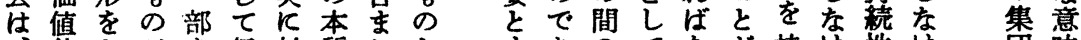
、体とがを伝対啠れと亦あのて肪け性け 団味

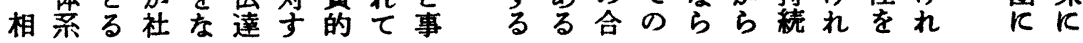


きむるの要奏のに、そミす間るュ来さはての、互

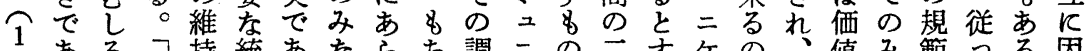
さあろ、持統あならち調二の三すケの值み範つる因 る、䄇発制るらゆろ和ケとつるイでそ体可开てと果

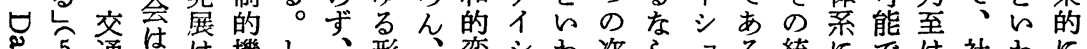

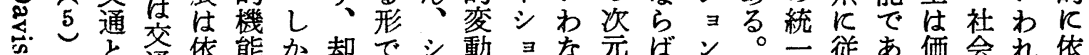

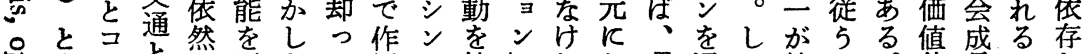
守ミと热否なて角ボ持しれお通か持と体員のし

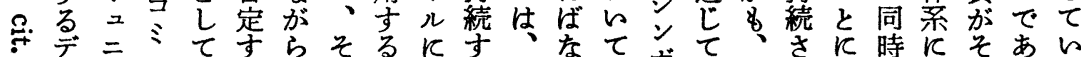

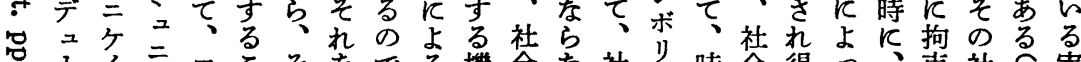

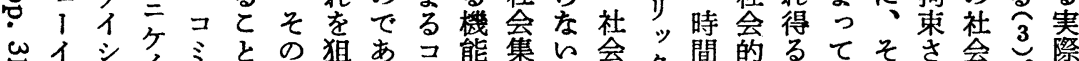
†の

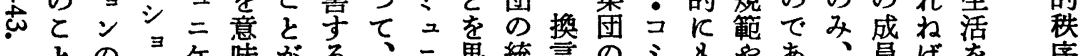

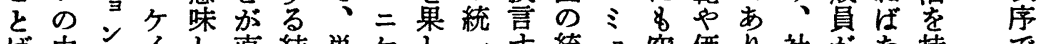
ば中不し直結単々し一統二空価り社がな持で

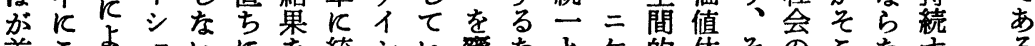

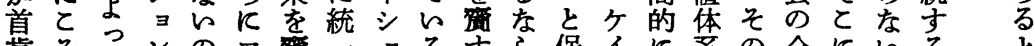

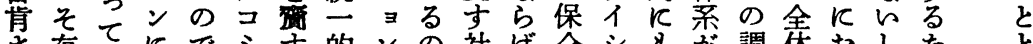

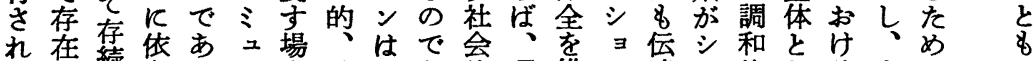

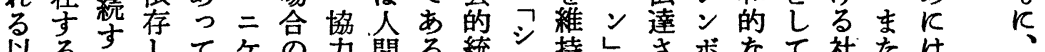

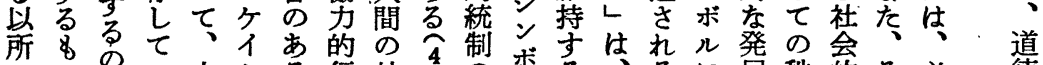

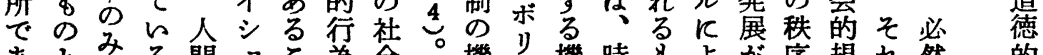

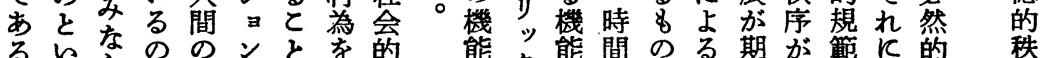
る。

るに分代 5 た

附 間を

文お化社しど人け社論以

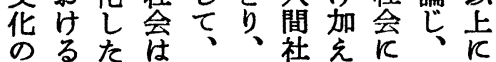
蓄比要之之質会なお法お 積類素のの的。がけけほ をなを範頂にそれるそて 考き炰域点は登な代引重人 棌飛位の展ら二要間 レンる躍守分とな二性社 れボよ的る化をいケを会

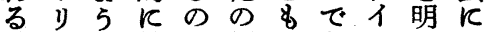
限ッに拡が傾にあシ りクな大近向、ろ 、合し代を量 らン得る 当コた社示的。のたコ 然ミ。そ会し飞発学

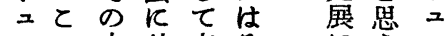
予 $=$ の内外来々 $飞 5=$ 想ケよ部なたのつのケ しイらにらと範施でイ 得シな極なと域ててあシ

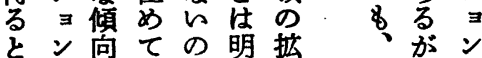
とさ向で複でか势 若芯の

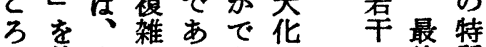
で前人なっあの の後質 あ提閏かてる。方 考に等

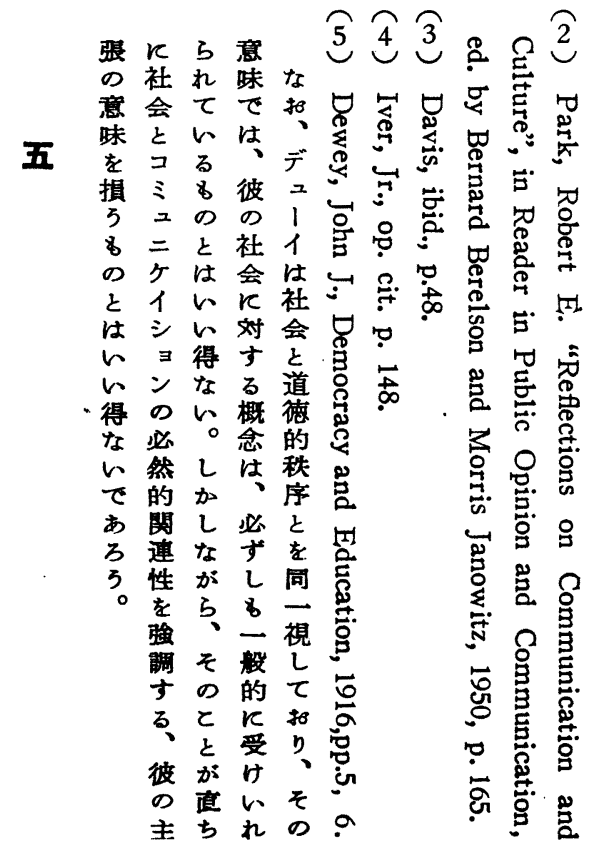




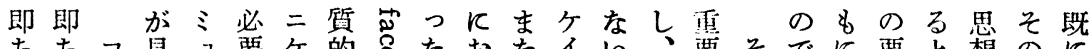

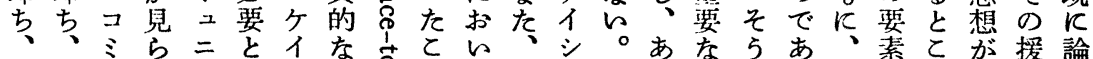

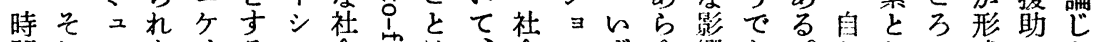

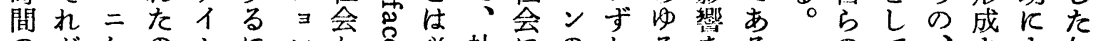

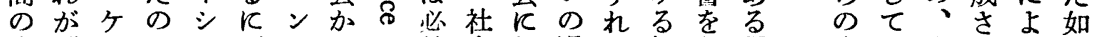
克運イでョ至のらの然会対過に個与限表の大れてく

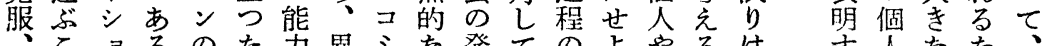

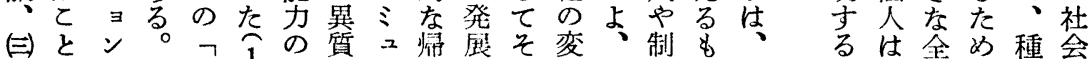
速のの原 $\underbrace{1}_{0}$ 增的二結との化社度のコ建体に令成 度出能初。大年でと変を会のでミ設その経の員

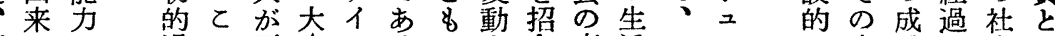

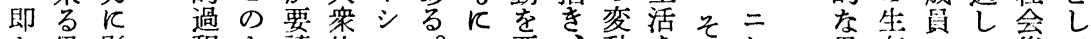
ち思影程よ清的 3 コ要、動をのケ思存とて集て

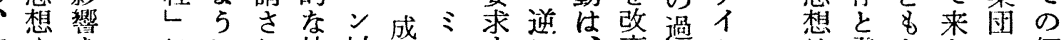
空やを 間感与加しる会上相二る、そ专の の情充えて結充の互ケ\&コれる変ン何の得史員は

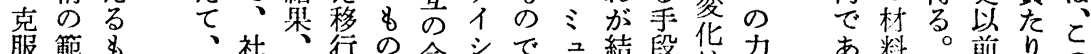
服範も方社行の合シでュ結段华力方料。前り の

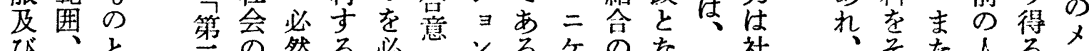

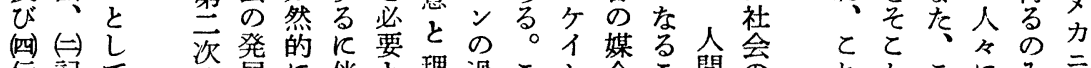

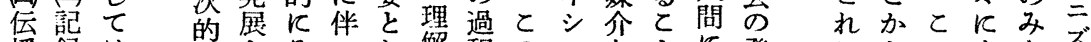

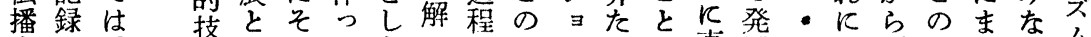

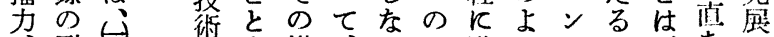

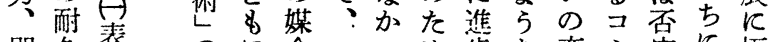

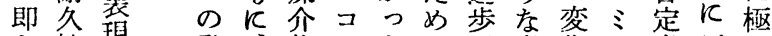
ち性㺺発物ミた飞名意化之出反め 達コを之同は起味は二来応て

つ引なでら台 加出古さ方通 加与孛か、通

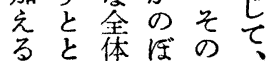

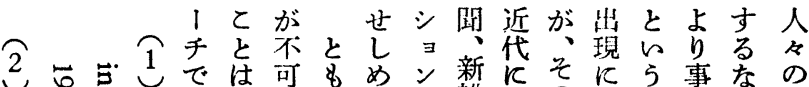

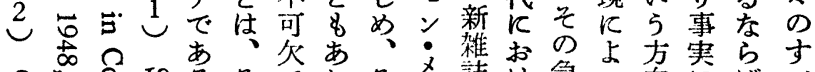

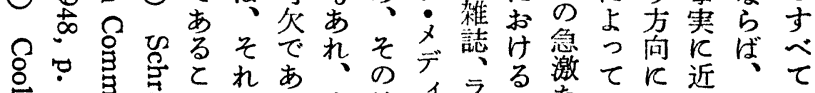

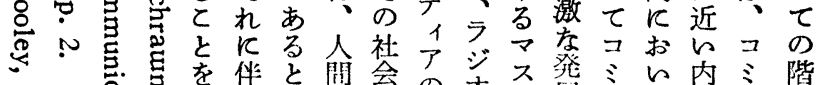

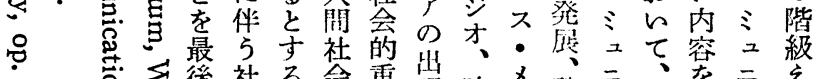

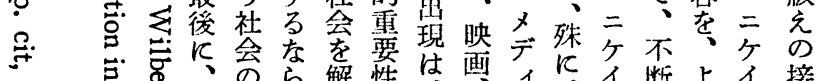

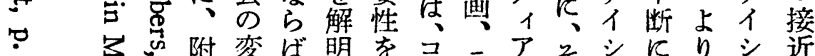

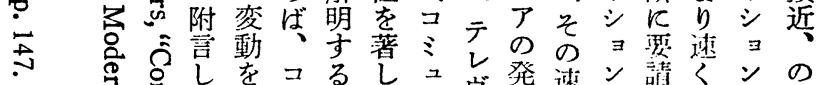

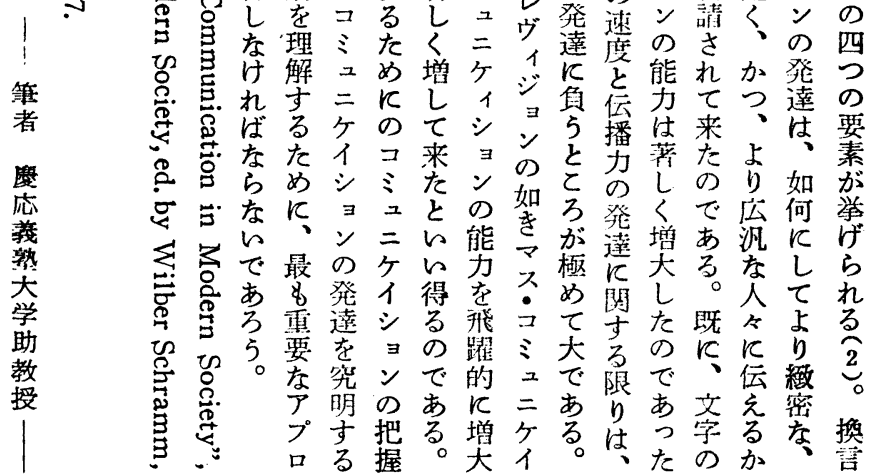




\title{
Communication in Human Society
}

\author{
Masaki Ikuta \\ Keio University
}

It is a real fact that many problems arise, as the communication in human society has been greatly changed in accordance with the turning up of the mass media. To study these problems of the communication of human society, we have to take the so-called "primary process" as Edward Sapir says into the consideration. Thus, in this aspect, this report will point out what characteristics the communication in human society have and what fnnction it will carry out.

It is clear that there must be some communication, among whatever it may be human or animal group as long as they lead collective life. Yet, the communication in human society is quite different from that of animal group. It is because that only human beings can use the symbol, and the communication of the human society is symbolic communication.

The symbol is arbitrary sign which has no relation with the experimental facts in its quality, then it does not loose its meaning even when it is separated from the logical coherence of the fact. These symbol include languages, letters, drawings, etc., and each has its own characteristics respectively.

It has a great significance in human development that human beings has such symbolic communication. That is, if culture is defined as Iver Jr. syas, "recurring patterns of behavior or results of behavior which are shared and which can be transmitted from group to group and generation to genertion", culture could not exist unless symbolic communication is premised because only symbolic communication is able to overcome time and space.

It is also said that the existence and the development of human society, as far the human society is understood as cultural scope, are surely depend on the mentioned communication. The symbolic communication has the function to maintain the unification and the harmonious change of human society.

This communication has been changed its phases recently in connection with development of the society. That is, there needs some media which makes the communication more effective, as the society assumes considerable enlargement and specialization, it is a matter of course mass media comes out consequently.

\section{Some Problems on the Measurement of the Scoio-economic Status in the Rural Villages under Reclamation}

\section{Hiroo Kaneda Hokkaido University}

Whether it is possible or not to establish any basic proposition in the quantitative understanding jof social phenomena? This study aims to outline the reflection on that question by experimental testing. The basic proposition examined here is that the measured results of the same object by different correct scales have relative conformity. To examine this, we used the "Socio-economic Status Scale" by F. S. Chapin and W. H. Sewell which is taken to be most effective on the research of this sort of social phenomena. We elaborated that seale considering the minimum needs to make a new one. And we made two more scales on its application. Selected objects for the study were three villages under reclamation 